Bernt Mфller

Dansk-fransk teknisk ordbog. Fonden for Fagsproglig Leksikografi, Handelshøjskolen i København, og Aschehoug Dansk Forlag A/S 1989.

Så kom den, den mig bekendt første dansk-franske angiveligt tekniske ordbog nogensinde. Foreløbig dansk-fransk, men snart også den anden vej. Med sit vakst udseende omslag, solide indbinding og handy format præsenterer dette første produkt i en ny serie af Clausens tekniske ordbøger sig godt. Indtrykket forstærkes umiddelbart af papirkvalitet, typografisk opsætning og til dels skrifttyper og af omfanget af forord, vejledning m.v.: 5 sider (af ca. 400) + for- og bagflap. Ikke hverdagskost for tekniske ordbøger.

I det følgende vil jeg gå lidt i dybden og fremkomme med en mere nuanceret kritik. Først kommenteres makrostrukturen, dernæst undersøger jeg kritisk fag- og lemmaselektionen. Efter nogle bemærkninger til mikrostrukturen til sidst en kort diskussion af ordbogens nytteværdi.

Dansk-fransk teknisk ordbog (DFTO) indeholder forside, forord, brugsvejledning, liste over forkortelser og tegn, liste over emneforkortelser samt selve ordlisten. Hertil kommer for- og bagflap.

Flapperne synes at være en blanding af reklame for ordbogen og af konkrete oplysninger, der ikke fremgår andetsteds. Denne cocktail har fået en fagligt set meget uprofessionel udformning, der ikke er et gennemarbejdet kvalitetsprodukt værdigt (se afsnittene om fag- og lemmaselektion).

Bevæger vi os ind bag titelbladet stiger kvaliteten. Forordet virker dog for traditionelt med sine kortfattede oplysninger om lemmabestand, fagområde, termgrundlag, ansvarlige m.v. Her savnes oplysninger om flere forhold. For det første nok så centralt om, hvad udgiverne forstår ved "teknisk sprog". For det andet om, hvor ordbogens termer er hentet inden de kom i den benyttede database og efter hvilke kriterier, de er selekteret herfra. For det tredje om hvem osv. de benyttede "fageksperter" er og hvilke "del[e] af ordbogsmaterialet" det er, disse har gennemset. For det fjerde om, hvem udgiverne overhovedet har lavet ordbogen for..., alt sammen typer af oplysninger, som burde være standard varedeklaration ikke mindst for nye ordbøger. Men der er da tale om en ikke uvæsentlig forbedring i forhold til den foregående serie af Clausens tekniske ord- 
bøger, hvis "frontmatter", herunder forordet, stort set er ikke-eksisterende.

Så er der mere information at hente i "Vejledning i brug af ordbogen" - hvis man vel at mærke har tålmodighed nok til at acceptere, at god forestillingsevne og flere gennemlæsninger af visse tekstafsnit er påkrævet, før meningen af de koncentrerede sætninger fremstår. Her burde der være illustreret med eksempler i stil med de efterfølgende gedigne illustrative symbol- og principforklaringer. Et nok lidt for højt terminologisk forudsætningsniveau præger denne del (medmindre målgruppen da kun er færdigtuddannede sprogfolk), jeg tænker på ord som glossering, oml $\phi b$, homograf.

"Forkortelser og tegn"-listen giver ikke anledning til kritik, udover at jeg principielt finder det uhensigtsmæssigt med oversigter, der er repræsenteret ved teksttyper, -størrelse og -snit forskellige fra dem, der figurerer i selve ordlisten.

Den fornuftigt separate oversigt over "Emneforkortelser" lister alfabetisk de 130 mere eller mindre arbitrære bogstavskombinationer, der er valgt til at repræsentere de forskellige tekniske discipliner. Meningen har givetvis været at finde bogstavskombinationer, der associerer i den rigtige retning, hvilket er en let opgave for de fleste: ZO for zoologi, VVS for VVS, VÆRK for værktøjer, værkstedsteknik. Knap så let har det af en eller anden grund været for TOUR (turisme), TEGNART (tegnekunst), POL (forurening) m.fl., hvor der er tyet til kunstgreb. Uigennemskulige er (ligeledes) MS for maskinteknik og -elementer og OGA for olie- og gasindustri; hvorfor ikke blot henholdsvis (f.eks.) TURISME eller TURIST, TEGNE eller TEGN, FORUR, MASKIN eller MASK, OLIEGAS eller OLIE?

Fagselektionen i en teknisk ordbog er mere kompliceret, hvis denne som den foreliggende prætenderer at dække de tekniske discipliner som sådan - man kunne vel kalde det en "almenteknisk" eller "alteknisk" ordbog — end hvis den begrænser sig til et, evt. flere fagområder. For hvormange og hvilke er de tekniske fagområder, "moderne teknisk sprog" dækker? DFTO anlægger en noget rummelig tolkning, idet den ikke kun omfatter, hvad de fleste vel vil opfatte som typiske, omend meget forskelligartede, tekniske discipliner/emneområder som f.eks. maskinteknik, grafisk industri, skovbrug og tandlægeudstyr, men også en længere række fag eller aktiviteter som malerkunst, spil, hobby, turisme og teater og, i den modsatte grøft, videnskabelige discipliner som kernefysik og matematik.

Ét spørgsmål er, om de 129 emner + multikategorien GEN (generelt) 
giver en tilstrækkelig og hensigtsmæssig dækning af de tekniske discipliner. Et andet, der overskygger det første, er, om alle disse emner opfylder forordets krav: "Det teknologiske samfunds udvikling medfører en stadig tilvækst af nye termer inden for teknisk sprog, som i dag er så omfattende, at en ordbog af dette omfang [30000 opslagsord] naturligvis ikke vil kunne dække ethvert behov, men der er ved udvælgelsen af opslagsordene lagt vægt på at medtage det centrale ordforråd inden for de behandlede emneområder" (min parentes og fremhævelse). En gennemgang af emneangivelserne for samtlige ækvivalenter på 10 fortløbende, tilfældigt udvalgte sider (pp. 301-310, incl.), svarende til ca. $1 / 40$ af ordbogens artikler, underbygger mistanken. Således afsløres en endog særdeles skæv procentuel repræsentation af de forskellige emner, spændende fra 13 for GEN, hvorefter følger EL (elektricitet, elektrisk udstyr) og VÆRK (værktøjer, værkstedsteknik) med hv. 12 og $10 \%$ samt MS (maskinteknik og -elementer), EDB, MET (metal, metalforarbejdning) og CHEM (kemi) med hver ca. 5-6\%. Herefter falder den relative forekomst hurtigt fra 2-3\% til blot få promille, og hele 44 emner (>1/3) er slet ikke repræsenterede! Hvis vi forudsætter, at denne tendens tilnærmelsesvist holder for hele ordbogen, indebærer det, at en lang række brede områder som kunst, botanik, biologi, kemisk industri, medicin, miljø, zoologi og økologi i bedste fald kun meget sporadisk er at finde i ordbogen. Et hurtigt opslag efter nogle få såvel formodet centrale som tilfældige termer inden for: kunst (akvarel, miniature, freskomaleri, koldnålsradering, kobbertryk), sport (off-side, obstruction, tie-break, tremeterkast, målspark, satbold), spil (skak, springer, ruder), botanik (vintergak, kronblad, pistil), zoologi (nasehorn, pungdyr, vekselvarm), turisme (turistbureau, vandcykel, sightseeing), medicin og kirurgi (skalpel, lungebetondelse, lårben, femur) viser ikke overraskende ikke-repræsentation over hele linien. Kun termen kobbertryk (dog også koldnålsarbejde og radering) er lemmatiseret, men med etiketten GRAF (grafisk industri). Det er alt andet lige måske nok et plus, at "mindre tekniske" discipliner ikke tager pladsen op for "den rene vare", men det er bestemt ikke hensigtsmæssigt, at køberen af ordbogen forledes til at tro, at denne kan medvirke til at dække hans behov for botaniske eller medicinske oversættelsesækvivalenter. Og det vil sikkert være tilfældet, for der er intet, der giver ham oplysninger om andet. En kommentar i forordet om den foretagne prioritering af emnerne må være et mindstekrav, men procentangivelser ved hvert emne ville være fin vejledning.

Bortset fra dette kritikpunkt forekommer de valgte emner og repræsentationen af flere af de væsentlige fornuftig. Dog springer det i øjnene, 
at det i dag vigtige bio-teknologiske område (biokemi, molekylær biologi, genetik, mikrobiologi, bioenergi, bio-informatik, etc.) glimrer ved sin ringe repræsentation - hvor er termer som kromosom, gensplejsning (genspaltning forekommer), DNA, genom, genbank, biochip, biocomputer, neuralt netvaerk ? Er områderne for dugfriske til at være kommet med i større omfang? I så fald er det på trods af følgende opgivne "garanti": "Ordbøgerne bliver til ud fra en fælles database,[...]. Databasen bliver løbende ført ajour, således at nye tekniske udtryk til stadighed kan finde vej til nye udgaver af ordbøgerne. Denne produktionsmetode giver samtidig en garanti for, at ordbøgerne ved udgivelsen er "up to date"" (fra for-flap). Som vi skal se, er manglende ajour-føring dog ikke et gennemgående fænomen.

Man kan diskutere, om der er tale om en heldig fagvægtning, når brede og potente discipliner som miljø, energi, forurening, solenergi, vindkraft og økologi, som alle findes som emneord, øjensynligt knap nok er repræsenteret. Er de ikke "tekniske" nok (- eller findes relevante termer fra disse discipliner under andre emneangivelser? I så fald er kritikpunktet uaktuelt, men emne-etiketteringen til gengæld kritisabel...)? Måske burde man have skåret ned på kvoten for de stærkt repræsenterede discipliner eller have nedprioriteret en række snævre emner som f.eks. papirindustri, radiopejling og -navigation, tekstilindustri m.fl., som at dømme ud fra den detailundersøgte del af ordbogen dominerer mere, end hvad der nok er rimeligt.

Hvilken funktion har emneangivelserne i øvrigt? Bagflappens formulering er ikke anvendelig: "[emneangivelserne][ ...] hjælper [...] brugeren til en mere præcis forståelse af det søgte ord eller udtryk". Nej; emneangivelserne kan derimod ofte med stor fordel bruges til at lette afgørelsen af, om man har fundet den optimale ækvivalent blandt flere mulige. Men i flere tilfælde, hvor der ikke er tale om polyseme lemmata, er denne information nok overflødig omend normalt ikke generende. Uklarheder forekommer dog, f.eks. hvor et lemma som libelle angivet som VÆRK også burde være benævnt MÅLTEK (måleteknik og -instrumenter) og GEODÆ (geodæsi), eller vel bedre: GEN.

Lemmaselektionen inden for udvalgte discipliner vil i det følgende blive genstand for en overordnet vurdering tilstræbt foretaget på basis af parametre som central karakter, aktualitet og deskriptivitet/præskriptivitet.

Informatik - i ordbogen søgt under det snævrere EDB - er i dag en meget central teknisk disciplin i relativt kraftig udvikling. De anslåede 
ca. 1500-1800 termer (på hvert sprog) forekommer at være et fornuftigt antal i en alteknisk oversættelsesordbog. Til sammenligning indeholder større engelsk-franske informatikordbøger i størrelsesordenen 3-10000 lemmata. Et opslag i DFTO efter nøgletermer i diverse nye danske informatikordbøgers/-lærebøgers indekser giver et billede af rimeligt god dækning — dog med undtagelser: joyball, tegneplade, grafikskarm, $L C D$, farveprinter, lommedatamat, håndterminal, elektronisk betalingsmiddel, benchmark program, firmware, hard copy. En systematisk gennemgang af alle EDB-lemmata med initialbogstavet a,b,c giver indtryk af, at ordbogens informatikindgange er af overordnet og ikke for specialiseret karakter, hvilket er helt på sin plads.

En fokusering på aktualitet, på graden af ajourføring, afslører ligeledes en $\varnothing$ jensynligt god følgen trit med udviklingen; vi noterer os således upto-date-termer som berøringsfølsom skarm, programmerbar tast og applikationsprogrammel. Andre mangler dog (se ovenfor). Indtrykket af rimeligt god ajourføring synes i øvrigt at finde støtte i højteknologiske nabodiscipliner som teleteknik og elektronik, se dog videre.

Et generelt problem i dag ved terminologisering og lemmatisering af tekniske neologismer uden for den anglofone verden er tacklingen af de angloamerikanske termer, der finder anvendelse i de pågældende andre sprog. I Danmark anbefaler sprogmyndighederne brugen af danskklingende termer som hjemmedatamat/personlig datamaskine for PC, programmel for software, datamat/datamaskine for computer, osv. Dette forhindrer som bekendt slet ikke sprogbrugere i at benytte de angloamerikanske termer, især ikke i kommercielle sammenhænge. Som flere danske (/engelsk-danske) informatikordbøger har DFTO da også valgt gennemgående at hælde til det præskriptive synspunkt. Således henvises under $P C$ til (personlig) datamaskine, under software til programmel. Derimod figurerer computer og dets komposita (med en enkelt lidt bizar undtagelse: computergrafik - klinger datamaskin(e)grafik for tungt? jamen hvad så med lemmaet datamaskinnet ?) uheldigvis ikke som henvisningsindgange, og det på trods af, at denne og andre oprindeligt anglomamerikanske termer sandsynligvis er mere frekvente i sprogbrugen end de foreslåede "danske". I enkelte tilfælde ses i DFTO lemmata, som ifl. fagfolk ikke er kurante, som f.eks. tidstro databehandling for realtime processing eller realtime databehandling (evt. realtids databehandling eller sandtids databehandling). Omvendt er der også hist og her et eksempel på angloamerikanske termer, hvis berettigelse er tvivlsom, som det er tilfældet for buffering, men balancen synes alt i alt god, dog savnes et større antal angloamerikanske henvisningsindgange. 
Et leksikalsk særkende ved disciplinen informatik synes at være betydningen af verberne, et forhold, der til dels afspejles i DFTO, der f.eks. medtager flere centrale kommandoer. Dog burde endnu flere uomgængelige verber lemmatiseres som indtaste, installere, klikke, konvertere...

Spørgsmålet er, om de for informatikken gjorte overvejende positive iagttagelser vedr. lemmaselektion kan ekstrapoleres til (de) andre fag. Undersøger vi en række mindre iøjnefaldende tekniske discipliner, nemlig landmåling/geodæsi, fotogrammetri, kartografi, bygningsafsætning og tegning, må vi desværre konstatere, at niveauet ikke helt holder. Selv om en række centrale termer er medtaget, mangler mindst lige så mange, ikke mindst af moderne karakter. Mens de klassiske instrumenter teodolit og nivelleringsinstrument findes i DFTO, mangler således den moderne laserteknikbaserede elektrooptiske distancemåler (EOD), herunder det i de seneste år helt uomgængelige landinspektørværktøj, totalstation. Tilsvarende finder vi planimeter, men ikke tachymeter, pantograf, men ikke koordinatograf, lodning, men ikke vatring og miring, højdekort, men ikke sфkort og plankopi, kote, men ikke hovedpunkt, faseforskel, men ikke brydningsindeks, projektion, men ikke geoide og datum, etc. etc. Flere af de fraværende må karakteriseres som centrale, men emnerne hører selvfølgelig ikke til blandt "de store". Uheldigt er det dog, at de på ny teknologi baserede instrumenter og opmålingsmetoder ikke er medtaget, jf. ovenfor. I den sammenhæng virker det lidt grotesk, og ikke just up-to-date, at en måleteknik fra forrige århundrede — landmåling med kade - optræder i ordbogen, og der er desværre en række eksempler på forældede/ikke-tekniske termer og termbetydinger som målestoksforhold (den tekniske term nu om dage er målforhold) og højdemåler og vinkelmåler i betydningen teodolit.

Vender vi os til kemien og den kemiske industri, viser der sig umiddelbart et billede af mange og relevante lemmata. Men også her mangler en del aktuelle, vigtige termer for stoffer og processer, m.v. (cholesterol, cortison, tocopherol, kritisk tryk, fluid, superkritisk ekstraktion). Et andet kritikpunkt er, at den prioriterede kemiske nomenklatur synes at være den gammeldags, dvs. ikke den også i Danmark anbefalede internationale, på latin baserede. Således er grundstofferne fosfor, ilt, klor de egentlige lemmata, mens hv. phosfor, oxygen, chlor kun er henvisningslemmata - og ikke omvendt. For kemiske forbindelser, herunder de organiske, synes man, hvilket dog i flere tilfælde er rimeligt, i endnu højere grad at have valgt en populær-deskriptiv og ikke en præskriptiv linie: carbon- 
hydrid må søges under kulbrinte, dinitrogenoxid under trivialbetegnelsen lattergas, calciumflorid under flusspat, glycerin under glycerol, ethyl under aetyl, etc. - til tider uden henvisning, selvom en sådan kunne være til hjælp i nogle tilfælde.

Ordbogen omfatter også "opslagsord af mere generel karakter, som der erfaringsmæssigt kan være brug for at slå op i forbindelse med oversættelsen af tekniske tekster", dem — eller rettere nogle af dem — med emneangivelsen GEN. Måske er det dem, der sigtes til på bag-flappen: "Ud over rent tekniske termer indeholder ordbøgerne også en række ord og udtryk af mere faglig art". Ordlyden er i øvrigt nonsens — der burde vel snarere have stået “... af mindre faglig art”. At medtage ikke-specifikt tekniske termer kan ideelt set være meget nyttigt, især hvis de anvendes med specielle oversættelser, herunder i mere eller mindre faste udtryk og kontekster, som for adjektivet effektiv i effektivt højdeforhold ( $\approx$ rapport des hauteurs d'entrée), men hvorfor medtage ækvivalenten til effektiv $\approx$ efficace; effectif?. Eller ukomplicerede substantiver, adjektiver, verber og adverbier som hv. façon $\approx$ GEN façon *; systematisk $\approx$ GEN systématique, méthodique; specialisere $\approx$ GEN spécialiser; absolut $\approx$ GEN absolument; (=ganske) purement; (=ubetinget) d'une manière (el. façon) absolu -?. Når man nu ved, at omfanget af ordbogen ligger fast, og at optag ét sted i sidste ende må medføre udeladelse et andet. Forklaringen er næppe at finde i ordbogens datamatiske conception - måske $\mathrm{i}$ udgivernes øjensynlige ønske om i hvert fald til en vis grad at gøre sig uafhængig af almensproglige ordbøger?

$\mathrm{Nu}$ nogle ord om mikrostrukturen. Ordbogens artikelopbygning og sammenføjning, der er efter nicheprincippet, virker gennemgående oversigtlig og konsekvent. Når det er sagt, er jeg dog ikke sikker på, at jeg kan se det hensigtsmæssige i, at "flerleddede opslagsord er anført under det centrale led eller det led, hvis oversættelse formodes at volde problemer", i hvert fald ikke, når princippet næppe er gennemført konsekvent (i det omfang, det overhovedet er muligt), og der ikke er henvisning. Hvorfor skal f.eks. absolut adressering $(\approx$ adressage absolu) søges under absolut, mens direkte adressering er at finde under adressering $(\approx$ adressage direct)?

De anvendte skrifttyper sammenholdt med den ret ringe trykketekniske kvalitet er ikke ideel, omend acceptabel. Det gælder især emneangivelserne, der ikke er tilstrækkeligt tydelige og for let flyder sammen med især ækvivalenterne. Men det gælder til en vis grad også lemmata og ækvivalenter, hvis typer er lige fede nok i forhold til afstanden bogstaver- 
ne imellem og i $\varnothing$ vrigt for uskarpe (man kunne om muligt med fordel have skelet til 1988-udgaven af Gyldendals dansk-franske eller af Munksgaards dansk-spanske ordbog). Et andet kritikpunkt er den uheldigvis meget varierende liniespatiering, der kan resultere i både ekstremt korte mellemrum, som på p. 15, 2. spalte, 4. linie:

\section{side 15}

og i ekstremt lange som på p. 58, 1. sp., 9. linie, hvor der havde været plads til en ækvivalent på ca. 9 bogstaver i tomrummet mellem lemma og emneangivelse...:

side 58

M.h.t. ækvivalensangivelserne er opstillingsmæssigt at bemærke, at man savner en oplysning om den eller de faktorer, der har bestemt rækkefølgen af synonyme og tilnærmelsesvist synonyme ækvivalenter, der tydeligvis ikke er struktureret efter et alfabetisk kriterium. Har vi måske at gøre med noget, der ligner frekvensbaserede iagttagelser, eller er det blot tilfældigheder, når lemmaet afhjoclpe efterfølges af ækvivalentsekvensen: remédier à, pourvoir à, suppléer à, parer à ? Det er heller ikke ideelt, når det — som det er tilfældet for adskillige ækvivalenter — er uklart, hvilke(t) ord, et bogstav efterfulgt af punktum til erstatning for enten en foranstående oversættelse eller et foranstående led af en oversættelse refererer til, som f.eks. den franske ækvivalent til den trafiktekniske term faseforskydning:

side 92

- hvad refererer $d$. til? déphasage ? décalage ? différence ? alle tre? I forbindelse med ækvivalenterne skal også lige nævnes, at der næppe er læst korrektur på alt materiale, for pletvis optræder (serier af) trykfejl, som under lemmaet forstyrrelse, hvor ækvivalenten perturbation både optræder med grafien pertubation (2 gange) og perbutation (1 gang).

Flere steder finder vi syntagmatiske sublemmata (tvetydigt benævnt "flerleddede underopslagsord" i Vejledningen) og kollokationer ("faste 
udtryk") som: dobbeltsadet ventil, manuel indlaseenhed, skrue over gevind, afladningsprøvning på frisk batteri, instrument til absolut måling, indspillet del af plade, etc. Både leksikaliserede syntagmer og faste og friere kollokationer er helt uuomgængelige del af teknisk kommunikation og bør i rigt mål præge en teknisk ordbog. Spørgsmålet er dog, om flere af ordbogens - i øvrigt ret få - kollokationer, som de sidstnævnte citerede, har en reel opslagsværdi (fra dansk til fransk). De franske synonyme termer surface gravée og plage de modulation kan sikkert adækvat oversættes med indspillet del af plade, men er dette en dansk term/kollokation, vi vil finde i en en dansk tekst? Hvis ikke, hører denne og lignende indgange kun hjemme i den kommende fransk-danske ordbog. For så kan pladsen bedre bruges til relevante danske faste udtryk som f.eks. vare $i$ vater og tage stikket $u d$.

De grammatiske oplysninger i DFTO er stort set begrænset til angivelse af ordklasse for homonyme lemmata af forskellig ordklasse, til oplysning om køn og tal for ækvivalenter (dog kun første graford i syntagmer) og til information om verbers eventuelle transitive og intransitive betydninger. Om der er brug for mere end dette basale minimum afhænger især af, hvilke brugerkategorier og formål ordbogen måtte være konciperet til. Nyttigt for mange i de fleste situationer ville i denne sammenhæng være indikationer af eller i hvert fald tentative retningslinier for fleksion på dansk og fransk af angloamerikanske termer, oplysninger om norm contra brug i henholdsvis Danmark og Frankrig (m.fl.) vedrørende bl.a. anglicismer samt ikke mindst kontrastiv information om orddannelsesregler for neologismer.

Parafraseringen ("glosseringen"), som et nærmest uomgængeligt værkt $\varnothing$ j til at finde den optimale ækvivalent, er benyttet i et vist omfang. Om dette er tilstrækkeligt til adækvate oversættelser over hele linien, må gentagen brug af ordbogen afgøre. Dog siger det sig selv, at det meget hyppige fænomen kvasi-synonymi, som markeret med semikolon, uden parentetiske oplysninger ingenlunde er ideel; hvad er f.eks. forskellen på følgende ækvivalenter til ventil: soupape *; valve *; clapet - ?

Derimod savner jeg ikke encyklopædiske oplysninger, som der da heller ikke er nogen af. De ville have taget alt for meget plads under de givne omstændigheder og er næppe heller teoretisk ønskværdige i en alteknisk etbinds-ækvivalensordbog.

Som annonceret først i anmeldelsen vil jeg til sidst se på ordbogens overordnede nytteværdi. Spørgsmålet er her ikke, hvordan en ideel tekniske ordbog kunne se ud, men det helt pragmatiske: hvem kan have gavn af DFTO? 
Som tidligere nævnt har vi ingen direkte oplysninger om målgrupperne for DFTO. Meget tyder dog på, at der primært, måske udelukkende, er tænkt på brugere med dansk modersmål, der skal oversætte til fremmedsproget fransk, hvilket er naturligt, men ikke selvfølgeligt. Her vil man vel især tænke på erhverssproglige studerende, praktiserende oversættere, terminologer m.v. Nu er det jo sådan, at der allerede findes værktøjer på markedet, som man normalt søger tilflugt til i oversættelsessituationer, typisk Gyldendals dansk-fransk ordbog (6. oplag 1988) og/eller Blinkenberg og Høybye: Dansk-fransk ordbog (under revision; 3. udgave 1975). Ingen af disse er angiveligt "tekniske", men en sammenholdelse er alligevel relevant. Det viser sig ikke overraskende, at Gyldendals indeholder de fleste af de tidligere søgte ikke-specifikt tekniske termer (inden for kunst, sport,...), de generelle (façon, systematisk,...) samt visse kollokationer, men stort set ingen specialiserede termer. B\&H omfatter, ud over hvad vi finder i Gyldendals + en meget stor mængde "almensproglige" ord og udtryk, tekniske termer på samme specialiseringsniveau som DFTO, til tider endda flere end i denne (geodæsi m.fl.). Til gengæld er flere af B\&H's lemmata og ækvivalenter tydeligvis ukurante i dag.

Det er urealistisk at forudsætte, at en potentiel bruger af DFTO i sit oversættelsesarbejde ikke sideløbende benytter en almensproglig danskfransk ordbog. På professionelt niveau vil Gyldendals ikke slå til i praksis, man kan f.eks. næppe undgå at støde ind i fagtermer af ikke-specifikt teknisk karakter. Spørgsmålet bliver ikke, om DFTO er et alternativ til Blinkenberg \& Høybye, men om DFTO er et vægtigt supplement til den. Hvis vi skal dømme ud fra 1975-udgaven af B\&H, vil svaret for mange brugergrupper nok være ja. Der er i DFTO medtaget en lang række nye termer, som vi ikke finder i B\&H, både lemmata og ækvivalenter, der ofte fremstår "renoverede" set i forhold til B\&H. DFTO's bredt-tekniske og ikke fagspecifikke og dybdeborende karakter gør dog, at specialiserede oversættere og terminologer med adgang til termbanker osv. næppe vil finde brug for denne ellers gennemgående gedigne ordbog, som dog ved fremtidige udgaver bør være endnu mere på forkant med den teknologiske og terminologiske udvikling end tilfældet er ved denne første udgave, herunder meget gerne i form af en "neologisme-guide" inden for de ny teknologier. 